\title{
TREATMENT AND OUTCOME OF HORSES WITH CUTANEOUS PYTHIOSIS, AND META-ANALYSIS OF SIMILAR REPORTS
}

\author{
Hoda Elkhenany ${ }^{1} \dagger^{*}$, Shady Nabil ${ }^{1,2} \dagger$, Howaida Abu-Ahmed ${ }^{1}$, Hassan Mahmoud ${ }^{3}$, \\ Ahmed Korritum ${ }^{1}$, Hoda Khalifa ${ }^{4}$
}

\begin{abstract}
${ }^{1}$ Department of surgery, Faculty of veterinary medicine, Alexandria University, Alexandria, Egypt, ${ }^{2}$ Brooke hospital for animals, Mansoura, Egypt, ${ }^{3}$ Department of Information systems, Faculty of computers and informatics, Banha University, Egypt, ${ }^{4}$ Department of Histology, Faculty of medicine, Alexandria University, Alexandria, Egypt

† Equal contributor
\end{abstract}

*Corresponding author, E-mail: hoda.atef@alexu.edu.eg

\begin{abstract}
Pythiosis is reported to be one of the most life-threatening infections of people and animals in tropical, subtropical and temperate areas worldwide. Infection can result from ingesting zoospores of Pythium insidiosum organism or from contact with water contaminated with zoospores. The ingestion of zoospores may result in enteric pythiosis, whereas cutaneous contact with zoospores/oomycete may result in cutaneous pythiosis. Here, we reported the clinical details of 10 horses with pythiosis introduced to our clinic. These horses were treated by excision of the lesion and application of an antifungal cream to the resulting wound. Also, we performed a meta-analysis of 214 horses, of 18 reports, affected with cutaneous pythiosis and analysed the influence of the horse's sex, age, lesion site, and treatment on outcome. Treatment of horses in these 18 reports varied from surgical excision, topical, regional or systemic administration of an antifungal drug, immunization, or a combination of treatments. Horses with the most successful outcome were those treated by excision of the lesionc oupled with systemic or topical administration of an antifungal drug. Horses treated by immunization responded the poorest.
\end{abstract}

Key words: pythiosis; skin lesions; equine; surgery; Pythium insidiosum

\section{Introduction}

Equine cutaneous pythiosis (ECP) is a granulomatous ulcerative disease caused byPythium insidiosum, an aquatic fungus-likepathogen (1, 2). The cutaneous lesion caused bythis pathogen has been described by some cliniciansas tumor-like, rounded, large, nodular granulomatous containing necrotic tissue and "irregularly shaped yellow-tan to grey, gritty, coral-like masses commonly calledkunkers or "leeches"

Received: January 2019

Accepted for publication: February 2019
(1). Kunkers, or "leeches"are composed of sequestered vessels, dead eosinophils, and Pythium hyphae and range in size from that of a grain of rice to several centimeters wide and several centimeters long (1). Kunkers can sometimes be found in dressings, when bandages are removed $(2,3)$. An epidemiological survey found the incidence of mortality of horses caused by pythiosis to be $1.3 \%$ in the Brazilian Pantanal region and 2.3\% in the Brazilian Cerrado region. The case fatality rate for infected horses was 23- 45.5 (4). 
Because the cell wall of the oomycete of Pythium insidiosum is comprised primarily of cellulose and B-glucan, an essential component of the cell wall, researchers have suggested that administration of an inhibitor of b-glucan synthesis, such as caspofungin, could be an effective treatment of animals for pythiosis (5, $6)$. The effectiveness of caspofungin in resolvingcutaneous pythiosis was tested by intraperitoneal injection in an experimentally induced pythiosis rabbit model, and resultsr evealed reduction in the growth of the lesions, but the lesions reappeared after treatment was stopped (7).

Radical surgery, including amputation of anaffected limb, is a common and effective treatment for pythiosis of human patients and animals(3, 8-10). Immunotherapy has been effective in treatment of human patients and animals for pythiosis, but results of immunotherapy vary $(3,11,12)$. Combining surgical therapy with immunotherapy is more effective than is immunotherapy alone or surgery alone (4, 13).

The aims of this study were to evaluate the effectiveness of topic antifungal cream application after surgical management in 10 horses suffering from cutaneous infection of Pythium insidiosum. We also, performed a meta-analysis of 214 horses, in 18 reports, affected with cutaneous pythiosis to evaluate the effectiveness of different methods of treatment. This analysis also examined the influence of age, sex, pregnancy and the site of the lesion on the outcome of the infected horses.

\section{Materials and methods}

\section{Case report history and clinical signs}

Ten horses, all of which were from the Delta region of Egypt, were presented to the Brooke Hospital for Animals (BHA) between July and September 2017 for treatment for cutaneous lesions of pythiosis. These horses had one or more exudative, ulcerative, edematous, granulomatous lesions (Fig. 1A). The presumptive diagnosis of pythiosis, based on the appearance of the lesion, was confirmed by histological examination of tissue excised from the lesion, using $H \& E$ and Masson's trichrome staining. The surface area $(\mathrm{A})$ of each lesion was calculated using following equation: $(\mathrm{A}=\pi \times r(a) \times$ $r(b)$, where $r(a)$ was the half $(1 / 2)$ of the longitudinal diameter and $r(b)$ was the $1 / 2$ of transverse diameter of the lesion.

The age, sex, pregnancy status of females, site, and size of the lesion of each horse were recorded. Also recorded the date where the horse was first examined, the date of $1^{\text {st }}$ surgery, date of recurrence, and the date at which the disease was considered to be resolved. Consent forms for treatment were signed by all owners.

\section{Surgical excision}

The horses were sedated with xylazine $\mathrm{HCl}$ (1.0 mg/kg, IV; Xylaject, Adwia, Egypt) and anesthetized with propofol (2 $\mathrm{mg} / \mathrm{kg}, \quad \mathrm{IV}$; Deprivan, Astra Zeneca, UK). The horses were then positioned in lateral or dorsal recumbency, depending on the site of lesion.

The lesion was excised with a scalpel, after preparing the lesion and surrounding skin for surgery, then we used curette to remove the superficial layer of the skin in case of large size lesions. An antifungal cream containing terbinafine $\mathrm{HCl}$ (Lamisil AT 1\% Cream; Novartis, Switzerland) was applied topically after surgery once daily for one week and covered with bandage. All horses were administered metronidazole (20 mg/kg, IV; Amrizole, Amriya pharm, Egypt), flunixin meglumine 0.50 $\mathrm{mg} / \mathrm{kg}$, IV; Flunix, Norbrook, U.K) and Procaine penicillin G (4 mg /100 kg, IM; Norocillin, Norbrook, U.K) for 5 days.

\section{Medline database analyses}

Our meta-analysis of studies of various treatments for human patients and animals for pythiosis included 37 studies. We divided these studies into in vitro and in vivo preclinical studies $(\mathrm{n}=19)$ and clinical studies $(\mathrm{n}=18)$. Twelve preclinical studies tested the sensitivity of $P$. insidiosum to various antifungal drugs, minerals, and herbal either in vitro alone $(n=7)$, in vivo a lone $(n=1)$ or both in vitro and in vivo $(n=4)$. Sev en preclinical studies were conducted to identify the molecular, proteomic, and genomic makeup of $P$. insidiosum. 
We computed the significance between each treatment group, 95\% confidence interval and sample odd ratio using Fisher exact test statistics using R program, ver.3.5.1

\section{Results}

Surgical removal followed by application of an antifungal drug

The 10 horses presented because of lesions caused by $P$. insidiosum were adults 3 to 11 years old (mean, $6.5 \pm 2.6$ years), weighing 300 to $360 \mathrm{~kg}$ (mean, $324 \pm 18.3 \mathrm{~kg}$ ). Three were male and 7 were mares. Four of the mares were pregnant. The cutaneous lesions were located on abdomen $(n=7$; the lesion of one extended caudally to include the mammary glands), shoulder $(n=1)$, thigh $(n=1)$, and fetlock $(n=1)$. The cutaneous lesions were ranged in size from 27 to $297 \mathrm{~mm}^{2}$ (mean, 147.64 \pm 123.1 ; Fig. 1).

The results of surgical excision and topical antifungal cream application showed that this protocol was effective in 7 out of 8 cases $(87.5 \%)$. One of the horses was lost to followup, and another one died after the second surgery as the lesion extended to the udder and animal was emaciated with very big lesion at the time of introduction. Four of the horses recovered after excision of the lesion, but for the other four horses, signs of recurrence of the lesion appeared after surgery. These 4 horses again underwent excision of the lesion 12 to 45 days (mean 22 days) after the first surgery. The average total cure time was $56.57 \pm 19.3$ days from the time of first surgery until the day of full recovery.

Microscopic examination of histological sections stained with H\&E or Masson's Trichome stain revealed fragments of hyphae surrounded by well-developed fibro-cellular capsule, connective tissue rich in collagen fibers, fibroblasts surrounded by esosinophils and radiating, esosinophilic material creating the histological appearance of the Splendore-Hoeppli phenomenon (Fig. 2).

The outcome of Medline database analysis of preclinical studies

The antifungal drug, terbinafine $\mathrm{HCl}$, was used to treat the horses for pythiosis, which is a fungal-like disease. In one in vitro study of the effects of various antifungal drugs on $P$. insidosum, miconazole was found to be the drug most effective against $P$. insidiosum, followed by ketoconazole (14). In other in vitro studies, some antifungal drugs were found to be ineffective against $P$. insidiosum (15). In one study, the antifungal drug caspofungin (lipopeptide) was found to have a limited fungistatic effect against $P$. insidiosum (7). In another study, the fungistatic effect of caspofungin on $P$. insidiosum was found to be similar to that resulting from immunotherapy but that treating a horse with caspofungin was more expensive than was treating a horse using immunotherapy (16). The efficacy of caspofungin against $P$. insidiosum was compared with that of other antifungal drugs in two in vitro studies, and in neither study was caspofungin found to be as effective as the other drugs $(17,18)$. Mefenoxam was found to have the highest fungal eradication $(<$ $90 \%$ ) in a study comparing the efficacy of caspofungin in resolving infection caused by $P$. insidiosum with that of itraconazole, posaconazole, voriconazole, terbinafine, and mefenoxam, Brown et al. (17). Argenta et al. (18) used caspofungin in combination with terbinafine, itraconazole, ibuprofen, or fluvastatin, and found the best combination for inhibiting growth of P.insidiosum to be terbinafine, itraconazole, and fluvastatin. Valente et al. (19) recently reported that plant-derived essential oils (EOs) and itraconazole worked synergistically to resolve infection caused by $P$. insidiosum in vitro. Some herbal extracts, such as propolis and garlic, which are known for their antifungal and antibacterial effect, have shown efficacy against $P$. insidiosum in vitro $(20,21)$.

The results of Zanette et al. (2013) study showed that an iron chelator, deferasirox, could ameliorate anemia caused by thalassemia but could not resolve lesions of pythiosis (22). They also reported that administering deferasirox in combination with immunotherapy resulted in dissemination of pythiosis to the lung. Zanette et al. (2015) treated rabbits for pythiosis with deferasirox in combination with the antifungal drug, micafungin, and reported and incidence of resolution of $88.2 \%$ (23). 
Sekhon et al. (1992) reported that the polyene antibiotics, like amphotericin B, were not effective against $P$. insidiosum (14), whereas another class of antibiotics as Macrolides and tetracycline were reported to be effective against $P$. insidiosum (24). These antibiotics exert their effect on $P$. insidiosum by inhibiting protein synthesis and inhibition of amino acid transport (25). Another study examining the effect of various antibiotics with antifungal activity against $P$. insidiosum found that gentamicin, neomycin, paromomycin, and streptomycin each had an inhibitory and fungicidal effect on at least $62.5 \%$ of all P. insidiosum isolates from equine pythiosis; tigecycline inhibited growth of $70.8 \%$ of the isolates (26).

In vitro studies examining the effect of various drug on $P$. insidiosum isolated from equine lesions are summarized in Table 1.

\section{The outcome of Medline database analyses of clinical studies}

Eighteen clinical studies involving 214 horses infected with $P$. insidiosum from 7 countries, including Australia ( $\mathrm{n}=5$ horses), Brazil $(n=106)$, Colombia $(n=1)$, Costa Rica $(n=39)$, Egypt $(n=43)$, Thailand $(n=1)$, and the USA $(n=19)$, were evaluated. The youngest adult horse (above one year old) in these studies was 2 years old, and oldest was 25 years old (mean, $11.45 \pm 6.3$ ) and foals (up to one year old) at ages ranged from 3 to 4 months with susceptibility rate only $6 \%$ in comparison to $94 \%$ for adults. The number of mares in the study group was $a b$ out 2.5 times greater than the number of males. Twenty one of 59 mares (38\%) for which information about pregnancy status was available were pregnant (Fig. 3).

Cutaneous lesions of pythiosis were most commonly found on the limbs $(54.12 \%)$ followed by abdomen (25.88\%). Less common locations of lesions included the mammary glands, the thorax, including the withers. Some horses had lesions of pythiosis in the nasal cavity or intestine.

Horses in these 18 clinical studies were treated by surgery, immunotherapy, injection of an antifungal drug into the lesion, or combination these treatments. In a report of 33 horses treated for pythiosis by surgery alone, $73 \%$ of horses had complete resolution of the lesions (27). Surgical excision of the lesion, coupled with oral administration sodium iodide for 2 weeks resulted in complete resolutions of lesions on the back and prepuce of a 3-monthold foal, but the time of follow-up for this foal was only 3 months (28). Statistical comparison between surgical approach alone and the empirical methods (developed by nonveterinarian where they used acids and another drugs combination) revealed a significant difference $(\mathrm{P}<0.05,95 \%$ Confidence interval $=1.09-23.59$ and odd ratio $=4.75$ ) between treatments (Figure 3D). Eighty percent of horses in our study had complete resolution of cutaneous pythiosis after they were treated by surgical excision of the lesion and by topical application of an antifungal cream to the resulting wound. In another study of horses affected with cutaneous pythiosis reported that $80 \%$ of horses had complete resolution of lesion after local injection with amphotericin B (8). When the antifungal drug, amphotericin B, administered by intravenous regional limb infusion (IV-RLP) after surgical excision to resolve lesions of pythiosis located on the distal portion of the limb, $92 \%$ of horses had complete resolution of infection (29). When amphotericin B administered in combination with $10 \%$ DMSO, $100 \%$ of horses had complete resolution of infection (30). The complete infection resolution was significantly higher among horses that received surgery and I V-RLP with amphotericin B than among horses that received surgery alone $(\mathrm{P}<0.0067$, $95 \%$ confidence interval $=1.39-24.06$ and odd ratio=5.14). The complete resolution of infection was significantly higher among horses that received IV-RLP with amp hotericin B, with or without DMSO, than among horses that were treated empirically $(\mathrm{P}<0.00001,95 \%$ confidence interval $=4.35-154.2$ and odd ratio=22.47) (Fig. 3). Immunotherapy alone was used to treat 36 horses for pythiosis in 3 studies $(4,12,13)$.

Immunotherapy combined with surgery was used to treat 24 horses for pythiosis in 4 studies $(3,4,11,31)$. There was no significant difference in incident of resolution between those 
horses that were treated with immunotherapy alone and those horses treated with surgery in addition to immunotherapy $(\mathrm{P}=1,95 \%$ confidence interval $=0.246-3.80$, and odd ratio=1). The outcome of horses in the group that received only immunotherapy was significantly better than the outcome of 15 horses treated empirically $(\mathrm{P}<0.001,95 \%$ confidence interval=1.78-42.87 and odd ratio=7.84). The outcome of horses were treated with a combination of immunotherapy and surgery was also significantly higher than the outcome of horses treated empirically $(\mathrm{P}<0.01,95 \%$ confidence interval $=0.00-116.7$ and odd ratio=0) $($ Fig. $3 \mathrm{~B})$.
One report described using photoablation with a neodymium: yttrium-aluminum garnet laser after excising the lesion of two horses to induce thermal necrosis of infected tissue that surgeons failed to remove at time of surgery (32). The authors reported that the lesions had not recurred after one year.

The results of all the published studies of horses undergoing treatment for pythiosis, including the number of horses in each study, age, sex, methods of treatment, and the incidence of resolution are summarized in Table 2.
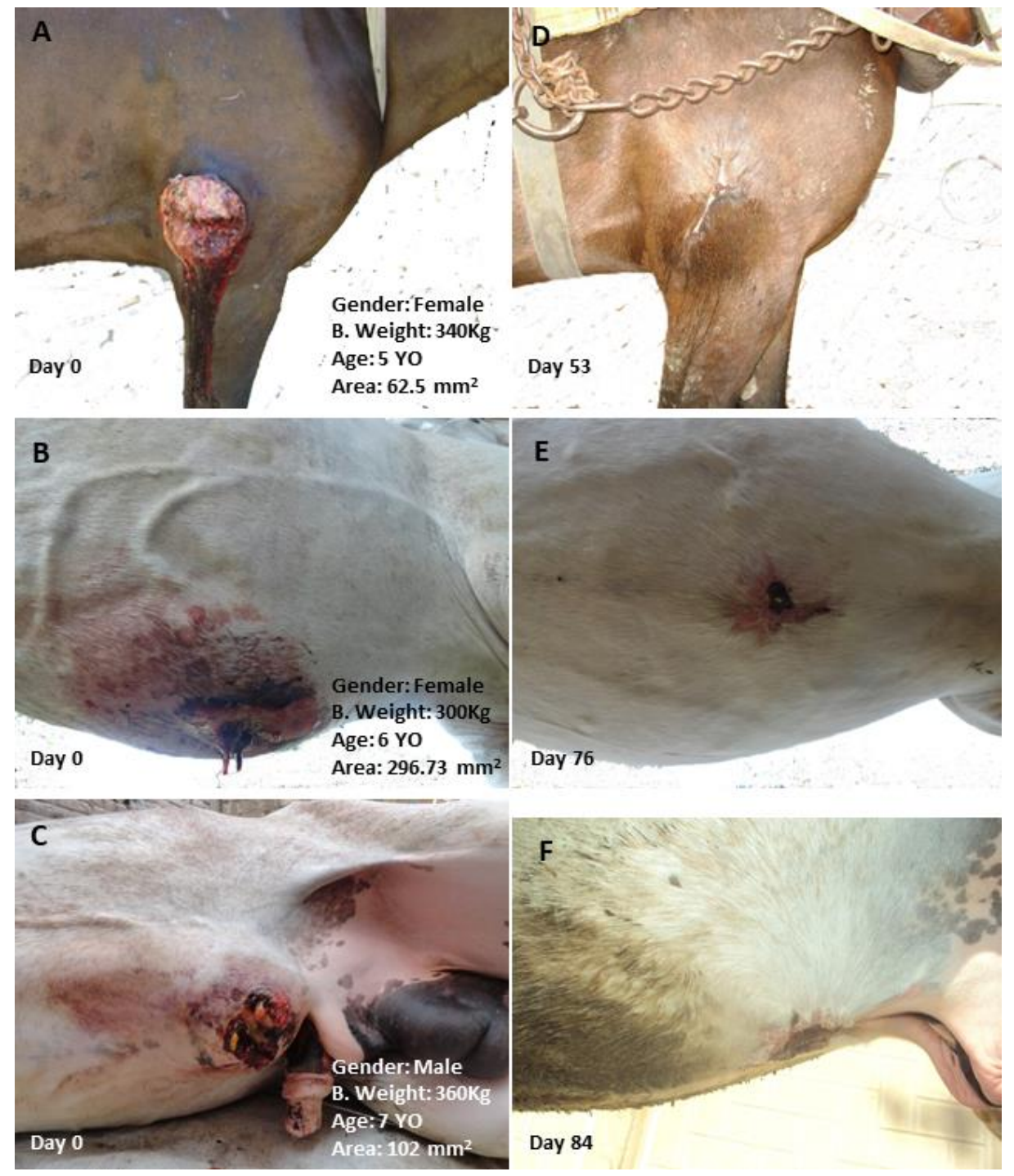

Figure 1: Representative clinical cases diagnosed as cutaneous pythiosis, before surgical intervention (A, $\mathrm{B}$ and $\mathrm{C}$ ) and after complete recovery (D, E and F). Each case has a brief information about the case as the gender, weight, age and the surface area of the lesion on the lower left corner of the image (A, B and C) also the day of the recovery at the lower right corner in (D, E and F) images 


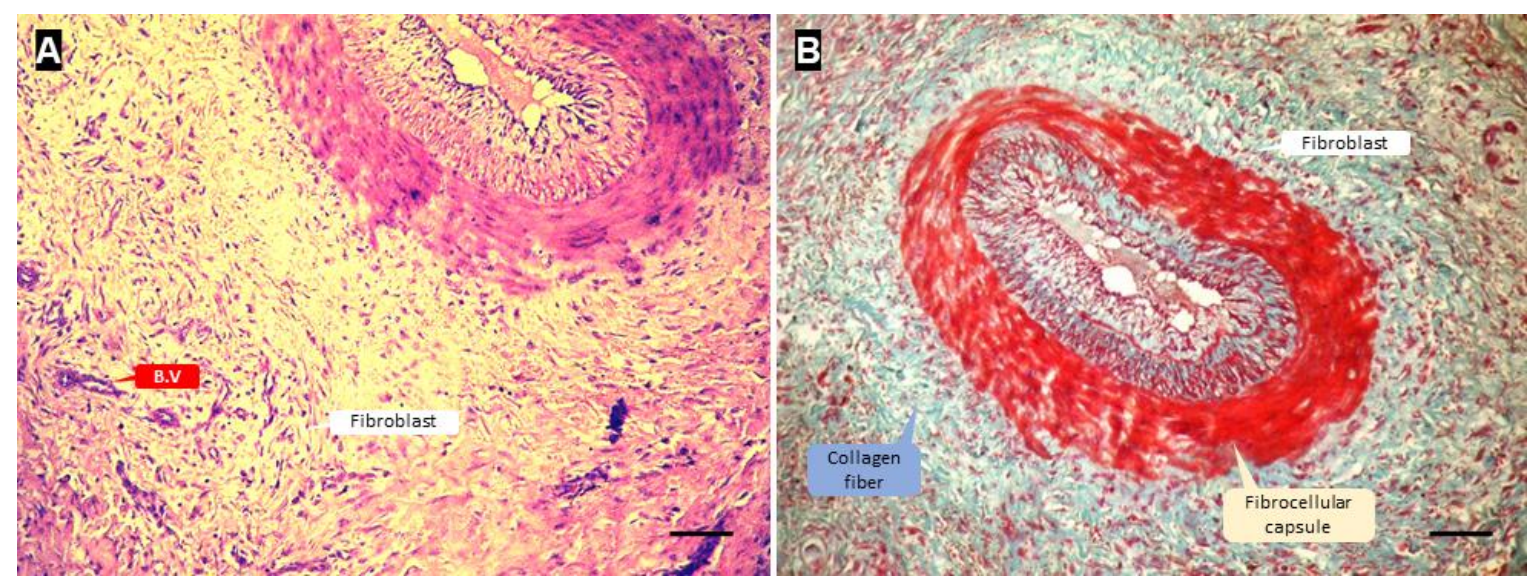

Figure 2: Representative histological section of skin lesion stained with H\&E (A) and Trichome Stain (B) showing the characteristic Splendore-Hoeppli like reaction. Scale bar $=500 \mu \mathrm{m}$

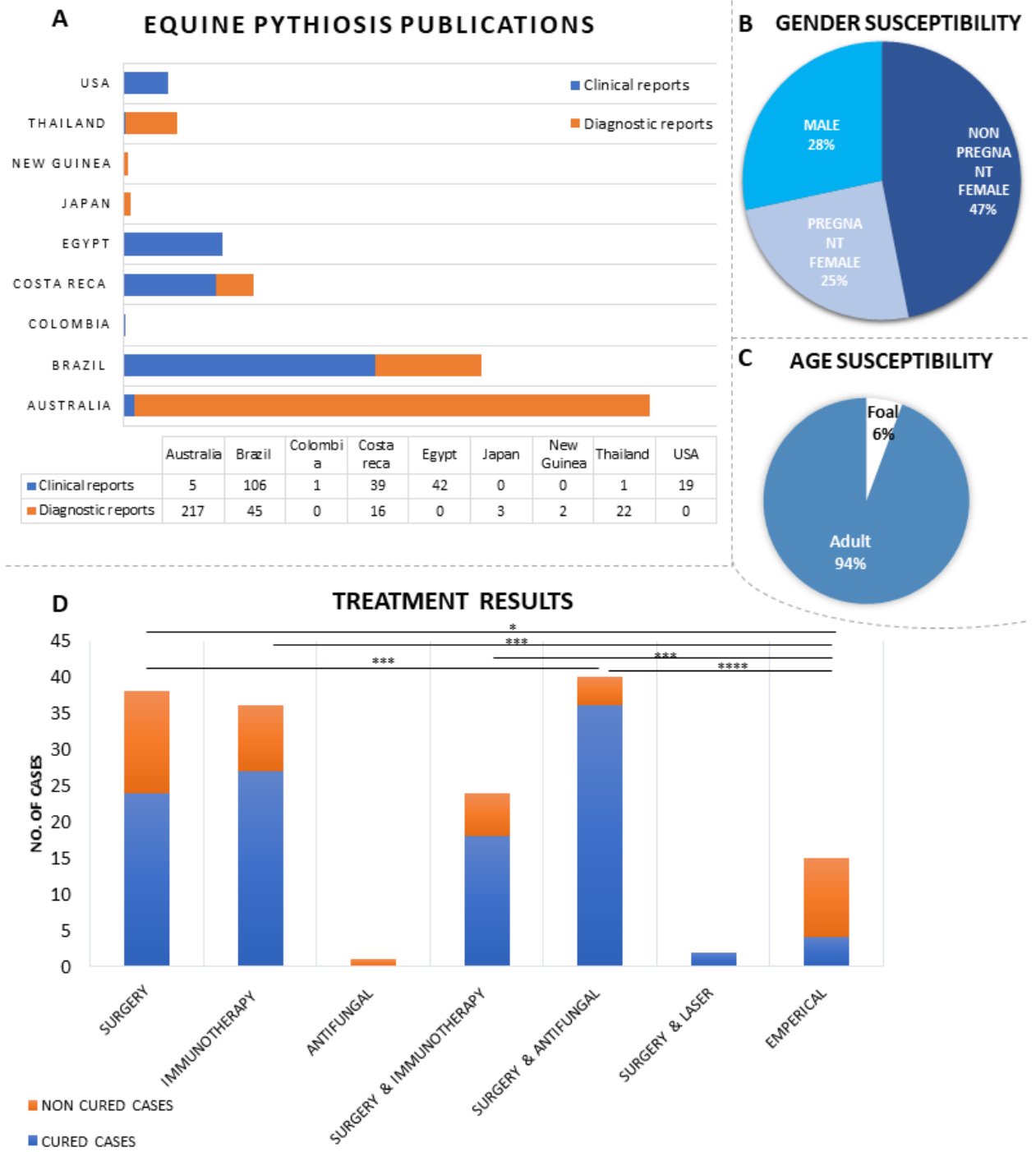

Figure 3: MEDLINE database analysis of clinical cases. (A) Publications around the world, bars represent no. of animals in all studies published/country (B) Gender susceptibility, (C) Age susceptibility and (D) MEDLINE database analysis comparing between different treatment approaches that have been used to treat equine pythiosis, $* \mathrm{P}<0.05$, $* * * \mathrm{P}<0.001$, $* * * * \mathrm{P}<0.000001$ 
Table 1: Summary of published preclinical studies in vitro and in vivo using different antifungal drugs, minerals and herbals to eradicate $P$. insidiosum

\begin{tabular}{|c|c|c|c|c|c|}
\hline Drugs & Drug under investigation & $\begin{array}{l}\text { In vitro/ } \\
\text { In vivo }\end{array}$ & $\begin{array}{l}\text { Animal } \\
\mathrm{M} / \mathrm{F} \\
\text { /Age }\end{array}$ & Results & $\begin{array}{l}\mathrm{RE} \\
\mathrm{F}\end{array}$ \\
\hline \multirow{5}{*}{ 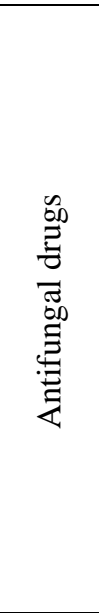 } & $\begin{array}{l}\text { Amphotericin B, hamycin, 5-fluo- } \\
\text { rocytosine, fluoconazole, itracona- } \\
\text { zole, ketoconazole and miconazole }\end{array}$ & In vitro & - & $\begin{array}{l}\text { P. insidiosum were sensitive to flucon- } \\
\text { azole, ketoconazole, and miconazole } \\
\text { and miconazole was the strongest one. }\end{array}$ & (14) \\
\hline & $\begin{array}{l}\text { Terbinafine, itraconazole, caspofun- } \\
\text { gin, ibuprofen and Fluvastatin }\end{array}$ & $\begin{array}{l}\text { In vitro } \\
\text { and In } \\
\text { vivo }\end{array}$ & $\begin{array}{l}\text { Rabbit } \\
(\mathrm{M} / 3 \mathrm{~m})\end{array}$ & $\begin{array}{l}\text { Terbinafine, itraconazole and Fluvas- } \\
\text { tatin combination resulted in the lowest } \\
\text { hyphae number. }\end{array}$ & $(18)$ \\
\hline & Caspofungin & $\begin{array}{l}\text { In vitro } \\
\text { and In } \\
\text { vivo }\end{array}$ & $\begin{array}{l}\text { Rabbit } \\
(\mathrm{M} \& \mathrm{~F} / 3 \\
\mathrm{m})\end{array}$ & $\begin{array}{l}\text { The results showed that caspofungin } \\
\text { has limited fungistatic activity against } \\
\text { P. insidiosum. }\end{array}$ & (7) \\
\hline & Immunotherapy and caspofungin & In vivo & $\begin{array}{l}\text { Rabbit } \\
(\mathrm{M} \& \mathrm{~F} / 3 \\
\mathrm{m})\end{array}$ & $\begin{array}{l}\text { No significant difference between both } \\
\text { treatments but the cost of the immuno- } \\
\text { therapy is lower than caspofungin. }\end{array}$ & $(16)$ \\
\hline & $\begin{array}{l}\text { Itraconazole, posaconazole, } \\
\text { voriconazole, terbinafine, caspofun- } \\
\text { gin, and mefenoxam. }\end{array}$ & In Virto & - & $\begin{array}{l}\text { Mefenoxam had a profound effect on } \\
\text { P. insidiosum at concentration } 1 \mu \mathrm{g} / \mathrm{ml} \\
\text { with }>90 \% \text { inhibition rate }\end{array}$ & $(17)$ \\
\hline \multirow[t]{2}{*}{ 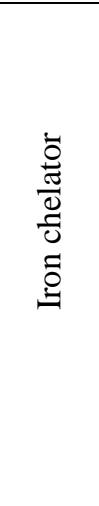 } & $\begin{array}{l}\text { Immunotherapy, Iron chelator de- } \\
\text { ferasirox and combination of both }\end{array}$ & $\begin{array}{l}\text { In vitro } \\
\text { and In } \\
\text { vivo }\end{array}$ & $\begin{array}{l}\text { Rabbit } \\
(\mathrm{F} / 3 \mathrm{~m})\end{array}$ & $\begin{array}{l}\text { Deferasirox alone did not result in any } \\
\text { significant enhancement for the lesion } \\
\text { from the control. However, it could } \\
\text { ameliorate the anemia. The combina- } \\
\text { tion between the immunotherapy and } \\
\text { iron were the worse than the immuno- } \\
\text { therapy alone. }\end{array}$ & $(22)$ \\
\hline & $\begin{array}{l}\text { Micafungin with or without defer- } \\
\text { asirox }\end{array}$ & $\begin{array}{l}\text { In vitro } \\
\text { and In } \\
\text { vivo }\end{array}$ & $\begin{array}{l}\text { Rabbit } \\
(\mathrm{F} / 3 \mathrm{~m})\end{array}$ & $\begin{array}{l}\text { Micafungin alone is not effective } \\
\text { against P. insidiosum but effective } \\
\text { when combined with deferasirox cure } \\
\text { rate } 88.2 \% \text { however, disease dissemi- } \\
\text { nation in the lung were reported. }\end{array}$ & (23) \\
\hline \multirow{3}{*}{ 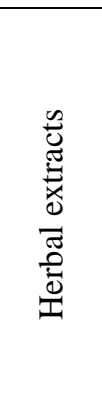 } & $\begin{array}{l}\text { Terbinafine or itraconazole with } \\
\text { Melaleuca alternifolia, Mentha } \\
\text { piperita and Origanum vulgare es- } \\
\text { sential oils (EOs) }\end{array}$ & In vitro & - & $\begin{array}{l}\text { The antimicrobial combinations using } \\
\text { EOs with terbinafine or itraconazole } \\
\text { can be an attractive therapeutic option } \\
\text { for controlling P. insidiosum infec- } \\
\text { tions. }\end{array}$ & (19) \\
\hline & $\begin{array}{l}\text { Propolis and geopropolis in a final } \\
\text { volume of } 1.0 \mathrm{~mL}\end{array}$ & In vitro & - & $\begin{array}{l}\text { Propolis was more efficient than ge- } \\
\text { opropolis in inhibiting P. insidiosum. }\end{array}$ & $(20)$ \\
\hline & Garlic extract & In vitro & - & $\begin{array}{l}\text { garlic extract has strong inhibitory ac- } \\
\text { tivity toward P. insidiosum }\end{array}$ & $(21)$ \\
\hline \multirow{2}{*}{ 导 } & $\begin{array}{l}\text { Macrolides and tetracycline antibi- } \\
\text { otics }\end{array}$ & In Virto & - & $\begin{array}{l}\text { Macrolides and tetracycline antibiotics } \\
\text { had an effective inhibitory effect for } \\
\text { the P. insidiosum }\end{array}$ & (24) \\
\hline & $\begin{array}{l}\text { Aminoglycoside antibiotics and } \\
\text { tigecycline }\end{array}$ & In Virto & - & $\begin{array}{l}\text { Tigecycline showed the lowest MIC } \\
\text { ( } 0.25 \text { to } 2 \text { mg/liter) and MFC ( } 1 \text { to } 8 \\
\text { mg/liter) range values. The in vitro sus- } \\
\text { ceptibility observed to tigecycline } \\
\text { makes this drug a good option for man- } \\
\text { agement of pythiosis }\end{array}$ & (26) \\
\hline
\end{tabular}


Table 2: Summary of published studies on clinical studies including the number of animals under investigation in each study, age, gender, methods of treatment and the recovery rate

\begin{tabular}{|c|c|c|c|c|c|c|c|}
\hline REF & $\begin{array}{l}\text { Place of } \\
\text { study }\end{array}$ & $\begin{array}{l}\text { Site of infec- } \\
\text { tion }\end{array}$ & $\begin{array}{l}\text { Cases } \\
\text { No }\end{array}$ & $\begin{array}{l}\text { Gen- } \\
\text { der }\end{array}$ & Age & $\begin{array}{l}\text { Treatment ap- } \\
\text { proach }\end{array}$ & Result \\
\hline (4) & Brazil & Cutaneous & 76 & - & 75 Adult & $\begin{array}{l}\text {-Immunotherapy } \\
\text {-Surgery and Immu- } \\
\text { notherapy } \\
\text {-Empirical }\end{array}$ & $\begin{array}{l}\text { Immunotherapy showed } 79.4 \% \text { efficacy } \\
\text { however, combination of immunotherapy } \\
\text { and surgery resulted in the highest recov- } \\
\text { ery rate } 84.6 \%\end{array}$ \\
\hline \multirow[t]{2}{*}{ (30) } & \multirow[t]{2}{*}{ Brazil } & \multirow[t]{2}{*}{ Distal limb } & \multirow[t]{2}{*}{15} & $7 \mathrm{~F}$ & \multirow[t]{2}{*}{$4 \mathrm{M}-15 \mathrm{Y}$} & \multirow[t]{2}{*}{$\begin{array}{l}\text { IRP of amphotericin } \\
\mathrm{B} \text { in a } 10 \% \text { DMSO }\end{array}$} & \multirow{2}{*}{$\begin{array}{l}\text { Complete resolutions of the lesion be- } \\
\text { tween } 6 \text { to } 9 \text { weeks after a single treat- } \\
\text { ment }\end{array}$} \\
\hline & & & & $8 \mathrm{M}$ & & & \\
\hline \multirow[t]{2}{*}{ (29) } & \multirow[t]{2}{*}{ Brazil } & \multirow[t]{2}{*}{ Distal limb } & \multirow[t]{2}{*}{12} & $8 \mathrm{~F}$ & \multirow[t]{2}{*}{$4 \mathrm{M}-10 \mathrm{Y}$} & \multirow{2}{*}{$\begin{array}{l}\text { Intravenous regional } \\
\text { perfusion (IRP) of } \\
\text { amphotericin B }\end{array}$} & \multirow[t]{2}{*}{$\begin{array}{l}\text { Complete lesion resolution in } 92 \% \text { of case } \\
\text { after } 35 \text { to } 60 \text { days }\end{array}$} \\
\hline & & & & $4 \mathrm{M}$ & & & \\
\hline (12) & Brazil & Cutaneous & 1 & $\mathrm{M}$ & - & Immunotherapy & $\begin{array}{l}\text { Lesion disappeared after } 5 \text { doses immuno- } \\
\text { therapy and the recurrence was detected } 2 \\
\text { years later in the abdomen }\end{array}$ \\
\hline \multirow{2}{*}{$\begin{array}{l}\text { This } \\
\text { study }\end{array}$} & \multirow[t]{2}{*}{ Egypt } & \multirow[t]{2}{*}{ Cutaneous } & \multirow[t]{2}{*}{10} & $7 \mathrm{~F}$ & \multirow[t]{2}{*}{$3-11 Y$} & \multirow{2}{*}{$\begin{array}{l}\text { Surgical excision fol- } \\
\text { lowed by local anti- } \\
\text { fungal injection }\end{array}$} & \multirow{2}{*}{$\begin{array}{l}\text { Most of them required a } 2^{\text {nd }} \text { surgical inter- } \\
\text { vention } \\
80 \% \text { Cure rate }\end{array}$} \\
\hline & & & & $3 \mathrm{M}$ & & & \\
\hline \multirow[t]{2}{*}{ (27) } & \multirow[t]{2}{*}{ Egypt } & \multirow[t]{2}{*}{ Cutaneous } & \multirow[t]{2}{*}{33} & $29 \mathrm{~F}$ & \multirow[t]{2}{*}{$3-9 \mathrm{Y}$} & \multirow[t]{2}{*}{ Surgical excision } & \multirow{2}{*}{$\begin{array}{l}\text { Surgical excision resulted in } 73 \% \text { cure } \\
\text { rate }\end{array}$} \\
\hline & & & & $4 \mathrm{M}$ & & & \\
\hline (8) & USA & Cutaneous & 10 & - & - & $\begin{array}{l}\text { Surgery followed by } \\
\text { Amphotericin B IV } \\
\text { and local }\end{array}$ & $80 \%$ Cure rate \\
\hline (31) & USA & Cutaneous & 3 & $\mathrm{~F}$ & $\begin{array}{l}1.5 \mathrm{Y}- \\
10 \mathrm{Y}\end{array}$ & $\begin{array}{l}2 \text { cases surgical exci- } \\
\text { sion } \\
1 \text { case surgery and } \\
\text { immunotherapy }\end{array}$ & $\begin{array}{l}\text { The treatment failed and all of them were } \\
\text { died. mammary part, nostrils, both limbs } \\
\text { and maxillary region, necropsy showed } \\
\text { granulomatous lesion in lung and liver }\end{array}$ \\
\hline (39) & USA & $\begin{array}{l}\text { Cutaneous, } \\
\text { extend to } \\
\text { bone }\end{array}$ & 1 & $\mathrm{~F}$ & $9 \mathrm{Y}$ & $\begin{array}{l}\text {-Antimicrobial and } \\
\text { sodium iodide, IV in- } \\
\text { jection } \\
\text {-Surgical excision } \\
\text { and regional antifun- } \\
\text { gal injection }\end{array}$ & $\begin{array}{l}\text {-Treatment with antimicrobials for } 12 \\
\text { days, debridement, and i.v. administration } \\
\text { of sodium iodide resulted in disease pro- } \\
\text { gression. } \\
\text { - Surgical excision and regional antifungal } \\
\text { injection were the most effective. }\end{array}$ \\
\hline (32) & USA & Cutaneous & 2 & - & - & $\begin{array}{l}\text { Surgery followed by } \\
\text { Photoablation }\end{array}$ & $\begin{array}{l}\text { Complete cure and no recurrence detected } \\
\text { for up to } 1 \text { year }\end{array}$ \\
\hline (13) & USA & Limb & 1 & $\mathrm{~F}$ & $18 \mathrm{Y}$ & Immunization & $\begin{array}{l}\text { The case did not respond to vaccine and } \\
\text { euthanized after } 5 \text { weeks }\end{array}$ \\
\hline (28) & USA & Cutaneous & 1 & $\mathrm{M}$ & $3 \mathrm{M}$ & $\begin{array}{l}\text { Surgery followed by } \\
\text { sodium iodide oral }\end{array}$ & Complete healing \\
\hline (41) & USA & $\begin{array}{l}\text { Enteric } \\
\text { pythiosis }\end{array}$ & 1 & $\mathrm{M}$ & $2 \mathrm{Y}$ & Surgery & No report about the recovery \\
\hline (3) & Costa reca & Cutaneous & 39 & - & - & $\begin{array}{l}\text { Surgery and Immu- } \\
\text { notherapy }\end{array}$ & $\begin{array}{l}\text { Only five horses were treated. } 3 \text { of them } \\
\text { respond to the treatment however the } \\
\text { other } 2 \text { cases did not respond as they were } \\
\text { chronic pythiosis }\end{array}$ \\
\hline (11) & Australia & Cutaneous & 5 & - & - & $\begin{array}{l}\text { Surgery, antifungal, } \\
\text { Immunization }\end{array}$ & $\begin{array}{l}\text { Surgery and antifungal were ineffective, } \\
\text { Vaccine resulted in } 1 \text { completely cured, } 3 \\
\text { developed osteitis and one died before } \\
\text { completing vaccine course }\end{array}$ \\
\hline (42) & Colombia & $\begin{array}{l}\text { Enteric } \\
\text { pythiosis }\end{array}$ & 1 & $\mathrm{~F}$ & $8 \mathrm{Y}$ & - & - \\
\hline (43) & Thailand & Nasal cavity & 1 & $\mathrm{~F}$ & $4 \mathrm{Y}$ & $\begin{array}{l}\text { Surgical removal, lo- } \\
\text { cal injection of mix } \\
\text { of Ampho. B, DMSO } \\
\text { and ringer lactate } \\
\text { then topical applica- } \\
\text { tion of antifungal } \\
\text { cream }\end{array}$ & $\begin{array}{l}\text {-Complete healing and recovery after } 3 \\
\text { Weeks }\end{array}$ \\
\hline
\end{tabular}




\section{Discussion}

Horses that develop pythiosis reside most commonly in a tropical, subtropical, or temperate region (33), and consequently, horses in most of the published reports of pythiosis were located in Australia, Brazil, Colombia, Costa Rica, Egypt, Thailand, and southern states in USA.

The presence of kunkers within granulation tissue is a grossly observable characteristic of cutaneous lesions of pythiosis, and the Splendore-Hoeppli phenomenon, an immunological reaction surrounding the causative agent, is a histologically observable characteristic.

Infection caused by $P$. insidiosum stimulate T-helper 2 (Th2) cells in the infected host, which causes eosinophils and mast cells to surround the hyphae of $P$. insidiosum. Degranulation of these cells leads to a Splendore-Hoeppli reaction. This reaction in horses is so intensive that kunkers develop (34).

Drugs interfering with the biosynthesis of ergosterol, like the azoles (itraconazole, ketoconazole, miconazole, and fluconazole), terbinafine, and amphotericin B, change the permeability of the cell membrane, causing lysis fungal cell. B ecause the cell membrane of the $P$. insidiosum is composed mainly of cellulose and $ß$-glucan, thus the above mentioned drugs $\mathrm{p}$ redictable to have little effect on $P$. insidiosum. Nevertheless, people and horses infected with $P$. insidiosum have been treated su ccessfully with drugs that interfere with the biosynthesis of ergosterol (35-37).

$P$. insidiosum has been reported to be sensitive to inhibitors of biosynthesis of ergosterol and $\beta$-glucan $(6,7,17,18,37,38)$. The efficacy of various antifungal drugs in the treatment of horses for pythiosis varied widely among the studies and depended on whether ergosterol was present in the cytoplasmic membrane of the oomycete $(14,34)$.

Not all antifungal drugs used to treat horses for pythiosis in these studies were effective against $P$. insidiosum. Caspofungin, for example, was found to be ineffective against $P$. insidiosum. Mefenoxam or a combination of antifungal drugs, such as terbinafine, itraconazole and fluvastatin, however, may be effective in inhibiting fungal growth and may provide a high incidence of resolution of infection. Data suggest that injecting the antifungal drug locally into the lesion or administering it by intravenous regional limb perfusion incr eases the likelihood of resolving infection $(8,29,39)$. Adjuvants, such as essential oils, iron chelators and DMSO have been combined with antifungal drugs to increase the efficacy of the antifungal drugs, in preclinical and clinical studies $(19,23,30)$.

The in vivo effect of a drug may be different than that expected based on in vitro testing of that drug. For instance, Sekhon et al. (14) showed that amphotericin was not effective against P. insidiosum, but Doria et al. (2012) reported that $92 \%$ of horses experienced resolution of lesions caused by $P$. insidiosum on one or more limbs when amphotericin B was administered by IV-RLP (29).

The herbal extracts, propolis and garlic, appeared to be effective against $P$. insidiosum in vitro, though we can find no reports describing the use of these herbs clinically $(20,21)$.

Adult horses have been reported to be 8 times more susceptible than foals to infection caused by $P$. insidiosum (4), but meta-analysis of the studies we report shows that adults appear to be 16 times more likely than foals to become infected with $P$. insidiosum. Meta-analysis of susceptibility according to gender showed that the females are more likely than males to be presented because of infection caused by $\mathrm{P}$. insidiosum (72\% vrs 28\%). Mendoza and Alfaro (1986), on the other hand, reported that pythiosis had no sex or age predilection (3).

Regarding the treatment, based on the metanalysis, we found that the best approach to be surgical excision coupled with application of an antifungal drug topically or, if the lesion was located on the distal portion of the limb, by IVRLP. There was no significant difference between the efficacy of immunotherapy used alone and the efficacy of immunotherapy used in conjunction with surgery. This can be explained by the short follow-up periods after the immunotherapy. Longer follow-up revealed that immunotherapy alone resulted in recurrence after 2 years as reported by Santos et al. 
(12). This may be explained by the progressive decrease in IgG antibody titers after administration of immunotherapy, which could result in titers too low to protect the host after one year (40).

\section{Conclusion}

The excision of a cutaneous lesions of pythiosis was proved to be an effective treatment of affected horses, especially when combined with local or regional administration of an antifungal drug. Also, combining DMSO with the antifungal has revealed a higher cure rate. Because propolis was shown to be effective against $\mathrm{P}$. insidiosum in vitro, we suggest testing its efficacy clinically. Including propolis in the treatment protocol is expected to be more efficient as it has antibacterial and antifungal in addition to its high regenerative capacity. Also, photoablation was suggested as effective treatment for horses with cutaneous pythiosis, but more studies are needed to prove its efficacy.

\section{Conflict of interest}

The authors declare that they have no conflict of interest.

\section{Limitations}

Some studies did not include enough data about the sex, age, and pregnancy status, so our analysis was based only on the studies that included that data.

\section{Acknowledgements}

The authors would like to express very great appreciation to Dr. James Schumacher (Professor of large animal clinical science, University of Tennessee) for editing this manuscript.

\section{References}

1. Chaffin, M.K., S. James, and W.C. McMullan, Cutaneous pythiosis in the horse. Veterinary Clinics of North America: Equine Practice, 1995. 11(1): p. 91-103.

2. Mendoza, L., L. Ajello, and M. McGinnis, Infections caused by the oomycetous pathogen Pythium insidiosum. Infecciones causadas por el patógeno oomiceto Pythium insidiosum. Journal de Mycologie Medicale., 1996. 6(4): p. 151-64.
3. Mendoza, L. and A.A. Alfaro, Equine pythiosis in Costa Rica: report of 39 cases. Mycopathologia, 1986. 94(2): p. 123-29.

4. dos Santos, C.E.P., et al., Epidemiological Survey of Equine Pythiosis in the Brazilian Pantanal and Nearby Areas: Results of 76 Cases. Journal of Equine Veterinary Science, 2014. 34(2): p. 270-4.

5. Hendrix, J.W., Sterol induction of reproduction and stimulation of growth of Pythium and Phytophthora. Science, 1964. 144(3621): p.1028-9.

6. Cavalheiro, A.S., et al., In vitro activity of terbinafine associated to amphotericin B, fluvastatin, rifampicin, metronidazole and ibuprofen against Pythium insidiosum. Veterinary microbiology, 2009. 137(3-4): p. 408-11.

7. Pereira, D.I.B., et al., Caspofungin in vitro and in vivo activity against Brazilian Pythium insidiosum strains isolated from animals. Journal of Antimicrobial Chemotherapy, 2007. 60(5): p. 1168-71.

8. McMullan, W.C., et al., Amphotericin B for the treatment of localized subcutaneous phycomycosis in the horse. J Am Vet Med Assoc, 1977. 170(11): p. 1293-8.

9. Chitasombat, M.N., et al., Clinicopathological features and outcomes of pythiosis. Int J Infect Dis, 2018. 71: p. 33-41.

10 Reanpang, T., et al., Vascular Pythiosis of the Lower Extremity in Northern Thailand: Ten Years' Experience. Int J Low Extrem Wounds, 2015. 14(3): p. 245-50.

11. Miller, R.I., et al., Complications associated with immunotherapy of equine phycomycosis. J Am Vet Med Assoc, 1983. 182(11): p. 1227-9.

12. Santos, C.E., et al., Does immunotherapy protect equines from reinfection by the oomycete Pythium insidiosum? Clin Vaccine Immunol, 2011. 18(8): p. 1397-9.

13. White, S.D., et al., Cutaneous pythiosis in a nontravelled California horse. Vet Dermatol, 2008. 19(6): p. 391-4.

14. Sekhon, A.S., A.A. Padhye, and A.K. Garg, In vitro sensitivity of Penicillium marneffei and Pythium insidiosum to various antifungal agents. European Journal of Epidemiology, 1992. 8(3): p. 427-32.

15. Madoui, M.A., et al., Sterol metabolism in the oomycete Aphanomyces euteiches, a legume root pathogen. New Phytologist, 2009. 183(2): p. 291-300.

16. Pereira, D.I.B., et al., Comparison between immunotherapy and caspofungin as agents to treat experimental pythiosis in rabbits. Journal de Mycologie Médicale, 2008. 18(3): p. 129-33. 
17. Brown, T.A., A.M. Grooters, and G.L. Hosgood, In vitro susceptibility of Pythium insidiosum and a Lagenidium sp to itraconazole, posaconazole, voriconazole, terbinafine, caspofungin, and mefenoxam. American journal of veterinary research, 2008. 69(11): p. 1463-8.

18. Argenta, J.S., et al., In vitro and in vivo susceptibility of two-drug and three-drug combinations of terbinafine, itraconazole, caspofungin, ibuprofen and fluvastatin against Pythium insidiosum. Veterinary Microbiology, 2012. 157(1): p. 137-42.

19. Valente, J.S., et al., In vitro activity of antifungals in combination with essential oils against the oomycete Pythium insidiosum. J Appl Microbiol, 2016. 121(4): p. 998-1003.

20. Araujo, M.J., S.M. Bosco, and J.M. Sforcin, Pythium insidiosum: inhibitory effects of propolis and geopropolis on hyphal growth. Braz J Microbiol, 2016. 47(4): p. 863--9.

21. Zanette, R., et al., In vitro susceptibility of Pythium insidiosum to garlic extract. African Journal of Microbiology Research, 2011. 5(29): p. 5316-8.

22. Zanette, R.A., et al., Iron chelation therapy as a treatment for Pythium insidiosum in an animal model. J Antimicrob Chemother, 2013. 68(5): p. 1144-7.

23. Zanette, R.A., et al., Micafungin alone and in combination therapy with deferasirox against Pythium insidiosum. J Mycol Med, 2015. 25(1): p. 91-4.

24. Loreto, E.S., et al., In vitro susceptibility of Pythium insidiosum to macrolides and tetracycline antibiotics. Antimicrob Agents Chemother, 2011. 55(7): p. 3588-90.

25. Rawn, C.D. and J.L. Van Etten, Mechanism of antibacterial antibiotic sensitivity in Pythium ultimum. Microbiology, 1978. 108(1): p. 133-9.

26. Mahl, D.L., et al., In vitro susceptibility of Pythium insidiosum isolates to aminoglycoside antibiotics and tigecycline. Antimicrob Agents Chemother, 2012. 56(7): p. 4021-3.

27. Mosbah, E., et al., Diagnosis and Surgical Management of Pythiosis in Draft Horses: Report of 33 Cases in Egypt. Journal of Equine Veterinary Science, 2012. 32(3): p. 164-9.

28. Chaffin, M.K., J. Schumacher, and N. Hooper, Multicentric cutaneous pythiosis in a foal. J Am Vet Med Assoc, 1992. 201(2): p. 310-2.

29. Doria, R.G., et al., Treatment of pythiosis in equine limbs using intravenous regional perfusionof amphotericin B. Vet Surg, 2012. 41(6):p.759-65.

30. Doria, R.G., et al., Evaluation of intravenous regional perfusion with amphotericin $\mathrm{B}$ and dimethylsulfoxide to treat horses for pythiosis of a limb. BMC Vet Res, 2015. 11: p. 152.

31. Reis, J.L., et al., Disseminated pythiosis in three horses. Veterinary Microbiology, 2003. 96(3): p. 289-5.

32. Sedrish, S., et al., Adjunctive use of a neodymium: yttrium-aluminum garnet laser for treatment of pythiosis granulomas in two horses. Journal of the American Veterinary Medical Association, 1997. 211(4): p. 464-5.

33. Pier, A., et al., Prominent animal mycoses from various regions of the world. Sabouraudia, 2000. 38(Supplement_1): p. 47-58.

34. Mendoza, L. and J.C. Newton, Immunology and immunotherapy of the infections caused by Pythium insidiosum. Medical Mycology, 2005. 43(6): p. 477-86.

35. Triscott, J.A., D. Weedon, and E. Cabana, Human subcutaneous pythiosis. Journal of Cutaneous Pathology, 1993. 20(3): p. 267-71.

36. Shenep, J.L., et al., Successful medical therapy for deeply invasive facial infection due to Pythium insidiosum in a child. Clinical infectious diseases, 1998. 27(6): p. 1388-93.

37. Grooters, A.M., Pythiosis, lagenidiosis, and zygomycosis in small animals. Veterinary Clinics: Small Animal Practice, 2003. 33(4): p. 695-720.

38. Cavalheiro, A.S., et al., In vitro activity of terbinafine combined with caspofungin and azoles against Pythium insidiosum. Antimicrobial agents and chemotherapy, 2009. 53(5): p. 2136-8.

39. Worster, A.A., et al., Pythiosis with bone lesions in a pregnant mare. Journal of the American Veterinary Medical Association, 2000. 216(11): p. 1795-8.

40. Gaastra, W., et al., Pythium insidiosum: an overview. Vet Microbiol, 2010. 146(1-2): p. 1-16.

41. Allison, N. and J.P. Gillis, Enteric pythiosis in a horse. J Am Vet Med Assoc, 1990. 196(3): p. 462-4.

42. Purcell, K.L., et al., Jejunal obstruction caused by a Pythium insidiosum granuloma in a mare. J Am Vet Med Assoc, 1994. 205(2): p. 337-9.

43. Tonpitak, W., et al., First confirmed case of nasal pythiosis in a horse in Thailand. JMM Case Rep, 2018. 5(1): p. e005136. 